0 FILME DE StANLEY Kubrick - que já tem mais de 30 anos -, marcoume profundamente desde a primeira vez que o vi. M esmo depois de assisti-lo outras três vezes, ainda me sinto empolgado pela sua mensagem semi-nebulosa (sem trocadilhos), pela magnífica fotografia e pelo encaixe perfeito da trilha sonora da obra de Strauss.

$\mathrm{N}$ a época, talvez até porque eu era 30 anos mais jovem do que hoje, este filme me transmitia algo de mágico, encantador e misterioso. Continuo fascinado pela história (escrita por Kubrick e Arthur Clarke), com marcadas tendências filosóficas, cujo pano de fundo mostra a incógnita da origem e destino do homem, discutindo na frente aspectos da conquista do espaço. Percebo que muitos outros foram impregnados pela aura desta obra e, assim, a saga permanece viva.

Parece inacreditável, mas já estamos de fato respirando os ares de 2001 e a odisséia (diz o Aurélio: 2 . fig. "viagem cheia de peripécias e aventuras") deverá agora também ser nossa, da revista e da SBEM / FEBRASEM .

U ma breve olhada para trás, mostra que nos últimos anos nossa sociedade vem assumindo posições mais atuantes e profissionais, tendo obtido conquistas importantes e ocupado espaços antes pouco ou nada explorados ou até - por tido antes como garantidos -, invadidos por outros.

A par da atenção e do empenho na manutenção destes espaços conquistados, mas tanto insuficientes quanto insatisfatórios, vamos agora um pouco além; vamos tentar a conquista do próprio "espaço". Aquele espaço que mencionei na edição de agosto, o veículo virtual para a transmissão, difusão e disseminação da ciência.

D everá ser o inicio de uma nova era de conquistas, desta vez na "internet"; de mostrarmo-nos e expormo-nos mais, de verificarmos se temos suficiente embasamento para vingarmos neste mundo novo e quase desconhecido. Digo quase, porque muitos colegas já vêm desenvolvendo um pouco deste trabalho, criando "sites" profissionais voltados para temas da especialidade e oferecendo a troca de informações importantes para os demais colegas. $N$ ão sei de todos, mas destaco aqui as iniciativas da SBD, do Departamento de Endocrinologia Feminina da SBEM, e particularmente, dos colegas: L aerte D amasceno, R eginaldo Albuquerque, J oão L indolfo Borges, Procópio do Vale, etc

Assim, convoco estes que já tem alguma vivência cibernética e todos aqueles que puderem e quiserem colaborar, para unirmos forças com 0 mesmo propósito. Estamos aceitando o desafio de conquistar novos horizontes e voar mais alto. Em dois anos deverei retornar ao tema, para checálo e estabelecer comparações, dimensionando retroativamente o poder de nossa ambição. Espero então poder estar afirmando o que gostaria de já estar dizendo agora. Este é o próximo e grande desafio. Luis César Póvoa já nos provocou a aceitá-lo. N ão há, portanto, como refugar ou aquietar-se.

O projeto SCIELO - Scientific Electronic Library O nline (www.scielo.org) é um programa brasileiro, desenvolvido por bibliotecários, técnicos e profissionais da BIREM E (Biblioteca Regional de M e-

\section{ClaudioE. Kater}


dicina, em São Paulo), com o apoio da FAPESP, que engloba no momento cerca de 50 revistas científicas brasileiras, tornando possível ao leitor internacional seu acesso e maior visibilidade. É um exemplo típico e atual, num país em desenvolvimento, da tendência de reestruturação do ciclo de informação científica que está acontecendo no mundo inteiro. I sto tem permitido, nos anos mais recentes, que nosso país (assim como outros em desenvolvimento) saia da grave marginalização imposta pela exuberante comunidade científica internacional, quase que exclusiva dos países desenvolvidos.

$O s A B E \& M$, entre outras revistas, foram préselecionados para candidatar-se à inclusão no rol do projeto SciELO em março próximo. Se aprovados, teremos condições de estar enviando nossa revista aos cuidados dos gerenciadores deste projeto e assim, poder expô-la e divulgá-la, através da "rede", a toda a comunidade internacional. Este será apenas o primeiro, mas o mais importante passo.

Infelizmente, nossa tímida experiência anterior de incursão na "rede", embutidos no "site" da SBEM $\mathrm{N}$ acional, foi frustrante e desanimadora. N ão por culpa ou desinteresse de nossa parte. Os responsáveis pela manutenção deste " site" jamais se incomodaram em atualizar nossos dados (enviados pontual e profissionalmente a eles à cada edição), à ponto de ao consultar nosso www.sbem.org.br no final do ano passado eu ter tido o dissabor de encontrar lá edições tão antigas, que meu editorial ainda convidava colegas a candidatarem-se à posição de editor-chefe. $\mathrm{N}$ ão sei o que muitos podem ter pensado durante todos estes meses passados, mas continuo firme na posição e disposto como nunca a desenvolver meu trabalho até a próxima troca, no final de 2002. E agora, uma vez incorporados no projeto SciELO, disposto a desenvolver um "site" próprio da revista com toda nossa produção científica podendo ser disseminada mais fácil e profissionalmente pelo "espaço".

Além disso, em caráter experimental ao longo deste ano de 2001, procurarei adaptar e utilizar o processo de submissão, revisão por pares, e outras trocas de informações pertinentes, diretamente na rede, reduzindo substancialmente o tempo (ainda longo) entre submissão e publicação dos manuscritos.

Estou certo que toda a comunidade científica nacional e, quero crer, também a internacional estarão se beneficiando da propagação de nossa ciência pelo espaço, à semelhança do que vêm acontecendo com quase todas as demais publicações. Livre e pronto acesso, sem restrições e sem formalidades. Evidentemente, 0 assunto é polêmico e muitas questões ainda precisarão ser resolvidas para que este processo funcione sem solavancos. M as este é o futuro das comunicações e estaremos nos fazendo presentes. 